\title{
Review
}

\section{Human rights as a way of life: On Bergson's political philosophy}

\author{
Alexandre Lefebvre \\ Stanford University Press, Stanford, 2013, v+181 pp., ISBN: 978-0804785792 \\ Contemporary Political Theory (2015) 14, e12-e15. doi:10.1057/cpt.2014.33; \\ published online 2 December 2014
}

Bergson's (2013 [1932], 1977) Two Sources of Morality and Religion, as Alexandre Lefebvre admits, is an unlikely place to look today for a theory of human rights. When Two Sources of Morality and Religion appeared in 1932, Bergson's influence was well on the wane. It met with silence or scorn in France and remained virtually unknown to Anglophone philosophers (p. xiii). Lefebvre's Human Rights as a Way of Life shows that this neglect is unwarranted. Rereading Two Sources of Morality and Religion does more than restore a lost chapter of French philosophy; it also provides a new and refreshing approach to human rights, and Lefebvre's is the first major treatment of the topic in Bergson. He offers a creative synthesis of contemporary human rights theory, the philosophy of self-care (Foucault and Hadot) and several generations of Bergson scholarship; the result should be of interest to a wide range of scholars. Lefebvre's thesis is that Bergson opens the door for a 'basic shift in perspective' about human rights (p. 138). Human rights should be seen as a kind of conversion or initiation into 'open love', that is, as a transformative event that introduces a 'disposition of the soul' (cited at p. 115).

In the first part of his book, 'Human Rights and the Picture of Morality', Lefebvre focuses primarily on Chapter 1 of the Two Sources of Morality and Religion and its critique of a certain 'picture' or 'image of morality' (p. 4). This image found morality on a rational faculty in rupture with organismic existence (cf. p. 37). The image also subscribes to a still pervasive brand of historico-social evolutionism, in which ideals of moral universality will be achieved through a gradual expansion of the moral community (pp. 4, 7).

Yet the persistence of war remains a constant challenge to this image. Durkheim's rationalistic sociology, Bergson's primary target here, remains incapable of confronting the fact of war since it confines morality to the sociological and neglects the ineluctable biological conditions of morality (p. 15). Rationalistic dualism cannot make sense of moral obligation, or the 'pressure' (pression) or the force proper to

(C) 2015 Macmillan Publishers Ltd. 1470-8914 Contemporary Political Theory Vol. 14, 3, e12-e15 www.palgrave-journals.com/cpt/ 
social moral norms. It makes obligation into something otherworldly, whereas obligation is in fact a naturally habituated tendency to play one's social role (Bergson, 2013 [1932], pp. 2, 12). There is a 'social cohesion written into our nature' (p. 67).

War is not a senseless aberration, but part of the very fabric of the closed society. Rationalistic moral philosophies sustain the illusion that moral commitments can be directed towards abstract rational agents, whereas every closed morality exists in a horizon of potential restriction to the in-group. The most immoral things are done to the enemy in the name of morality (p. 44); this closure is biologically based, thus belying Durkheim's optimism regarding the reconciliation of national and cosmopolitan moral duties (p. 40). Bergson's turn to biology has two consequences: (i) a rejection of 'veneer theory' (the primatologist Frans de Waals' term), the idea that we are not naturally moral, but (ii) an acknowledgement of the natural propensity to war (p. 53). We are naturally moral, but this morality is naturally limited.

Yet, Bergson paradoxically seeks to unite 'evolutionary theory, voluntarism, and the crisis of modernity' in his analysis of morality and politics (p. 86). Bergson's crucial distinction between the open and the closed allows him to suggest that the very limitation of in-group morality can be overcome, not through an anti-natural or transcendent intelligence or social evolution, but through a second biological 'source'. Bergson is biologistic without denying human freedom; human rights themselves are also natural (p. 54). Lefebvre claims that Bergson flies in the face of the current 'postmetaphysical' (Rawls, Ignatieff, Nussbaum, Rorty) interpretation of human rights as politically justified and without need for metaphysical backing: Bergson 'explicitly says that he searches for a ground for morality ... that is more "metaphysical than moral in its essence", (p. 28). Caution is, however, in order here. The passage Lefebvre cites is actually about mystical love (Bergson, 2013 [1932], 1977, pp. 248 [234]). If Bergson (1934), unlike Heidegger, continues to think of himself as doing metaphysics, it is certainly not in the sense of a foundationalist philosophical system (pp. 235-237). Morality has two sources, but these are not first principles.

How can Bergson simultaneously affirm the biological universality of war and maintain possible biological basis for overcoming moral closure? The second part of Lefebvre's book, 'An Introduction to the Open Life', attempts to show how human rights, as the cornerstone of this open morality, can be thought without recourse to a self-grounding practical reason. Although human rights are often conceived in terms of political and legal measures to protect people from harm, Lefebvre's most original suggestion is to treat them in addition as forms of self-care or processes of conversion (p. 73). Conversion is to be heard not as epiphany, but rather, following Foucault and Hadot, as spiritual exercise (pp. 77-79).

Crucially, conversion does not imply transcending life. For Bergson (1941 [1907]), the simple movement of life must be understood according to two perspectives: the static 'arrest' of life in its differentiation into species and the generative and undifferentiated movement of life in general (the élan vital) as continual upsurge of novelty 
(pp. 238-271). 'Humanity as a whole cannot bend nature to its will [ne saurait la forcer]. But it can get round it [la tourner]' (Bergson, 2013 [1932], 1977, pp. 291 [274]). The open life, in short, might require surpassing the species condition, without thereby abandoning life as élan vital (pp. 86, 106-107). Certain spiritual techniques of conversion, while remaining utterly immanent to life, can take up life in its becoming and overcome the human condition. Lefebvre is thus able later to deploy Bergson against Deleuze's criticisms of human rights, showing that Bergson offers a way to think human rights without the humanistic subject (pp. 134-136; cf. Lefebvre, 2011).

The transition from closed to open morality, from in-group to all of humanity (and possibly all of life), is not gradual, but occurs in a leap (saut brusque) (for example, Bergson, 2013 [1932], p. 73). The impetus behind this transition is emotion and above all love, but of a different sort than in the closed society. Open love is concretely manifested in great historical examples of mysticism (p. 102). Strikingly, mysticism for Bergson is not an experience of transcendence to life, but rather a plunge back into the generative movement of life itself (pp. 103-104). It is active rather than quietistic. The emotion of open love is not a mental state that the subject 'has'; it is the conversion of the soul to something greater than the individual (p. 108).

In closing, Lefebvre clarifies that he is not attempting to eliminate the juridical understanding of human rights. Human rights are rather composite (in Bergson's sense): they have both open (self-transformative) and closed (juridical) tendencies (pp. 138-139). Lefebvre suggests three lines of future development: (i) he permits a new reading of the canonical human rights thinkers; (ii) he offers 'an alternative genealogy for human rights' that brings in 'discourses of self-care, spiritual exercise and ascetic'; and (iii) he discloses the dynamic and self-reinventing potentialities of human rights (pp. 141-142).

This last suggestion is perhaps the most interesting. Although Bergson does not use the phrase himself, we might say that he allows us to see through a certain 'picture' of universalism predicated upon a static human nature or human reason, opening up space for a dynamic and self-transformative universality. This sort of ethics, resting on a vital spirituality with no transcendent telos, would not provide eternally binding principles, but it would also not shy away from translating itself into laws and norms.

In many ways, the most striking aspect of Lefebvre's book is his analysis of love. Yet love is far from the only emotion Bergson considers in Two Sources of Morality and Religion. To cite just one particularly privileged example, Bergson also emphasizes joy (joie), which he contrasts with mere pleasure (plaisir) (Bergson, 1934, pp. 116, 142; Bergson, 2013 [1932], pp. 57, 225, 338; cf.). It would be interesting to ask how joy might be reimagined as an experience conversion without specific content. Is the love involved in human rights always a joyous one? An important dimension of some human rights discourses today is the mourning of past atrocities. What does the Bergsonian plunge into the generative becoming of life make of mourning and death and their potential for conversion? 


\section{References}

Bergson, H. (1934) La pensée et le mouvant. Paris, France: PUF.

Bergson, H. (1941 [1907]) L'évolution créatrice. Paris, France: PUF.

Bergson, H. (1977) The Two Sources of Morality and Religion. Translated by R. Ashley Audra and Cloudesley Brereton, with W. Horsfall Carter. Notre Dame, IN: University of Notre Dame Press.

Bergson, H. (2013 [1932]) Les deux sources de la morale et de la religion. Edited by Frédéric Keck and Ghislain Waterlot. Paris, France: PUF 'Quadrige'.

Lefebvre, A. (2011) Human Rights in Deleuze and Bergson's Later Philosophy. Theory and Event 14(3). Project MUSE, <http://muse.jhu.edu/>, accessed 31 July 2014.

Alex Feldman

Pennsylvania State University, University Park, PA 16802, USA 